Article

\title{
Carbon Footprint Analyses and Potential Carbon Emission Reduction in China's Major Peach Orchards
}

\author{
Chaoyi Guo ${ }^{1}$, Xiaozhong Wang ${ }^{1}$, Yujia Li ${ }^{1}$, Xinhua He ${ }^{1}$ (D) , Wushuai Zhang ${ }^{2}$, Jie Wang ${ }^{1}$, \\ Xiaojun Shi ${ }^{1,2,3}$, Xinping Chen ${ }^{1,2}$ and Yueqiang Zhang 1,2,3,* (iD) \\ 1 College of Resources and Environment, Southwest University, Chongqing 400716, China; \\ chaoyiguo_1994@163.com (C.G.); 08.wangpeng@163.com (X.W.); 18883734152@163.com (Y.L.); \\ xinhua.he@uwa.edu.au (X.H.); mutouyu@swu.edu.cn (J.W.); shixj@swu.edu.cn (X.S.); \\ chenxp2017@swu.edu.cn (X.C.) \\ 2 Academy of Agricultural Sciences, Southwest University, Chongqing 400716, China; wszhang2008@163.com \\ 3 National Monitoring Station of Soil Fertility and Fertilizer Efficiency on Purple Soils, Southwest University, \\ Chongqing 400716, China \\ * Correspondence: zhangyq82@swu.edu.cn; Tel.: +86-23-68-251-249
}

Received: 5 July 2018; Accepted: 14 August 2018; Published: 16 August 2018

check for updates

\begin{abstract}
An excess of material input in fruit orchards has brought serious environmental problems, particularly in China. However, studies on the estimation of greenhouse gas (GHG) emissions in peach orchards are limited. In this study, based on questionnaire surveys in major peach-producing regions, including the North China Plain $(n=214)$, as well as northwest $(n=22)$ and southwest $(n=33)$ China, the carbon footprints (CFs) of these orchards were calculated by the life cycle assessment. The potential emission reduction in each region was estimated by combining the GHG emissions and CFs with plantation areas and fruit yields. The results showed that the average GHG emissions in the North China Plain, northwest, and southwest regions were 15,668 $\mathrm{kg} \mathrm{CO}_{2}$-eq ha ${ }^{-1}$, $10,386 \mathrm{~kg} \mathrm{CO}_{2}$-eq ha ${ }^{-1}$, and $5580 \mathrm{~kg} \mathrm{CO}_{2}$-eq ha ${ }^{-1}$, with corresponding $\mathrm{CFs}_{\text {of }} 0.48 \mathrm{~kg} \mathrm{CO}_{2}$-eq ha ${ }^{-1}$, $0.27 \mathrm{~kg} \mathrm{CO}_{2}$-eq ha ${ }^{-1}$, and $0.20 \mathrm{~kg} \mathrm{CO}_{2}$-eq kg ${ }^{-1}$, respectively. The main contribution source of GHG emissions in these three regions was fertilizer (77-95\%), followed by electricity, pesticides, and diesel. By adopting advanced farming practices with high yield and a high partial factor productivity of fertilizer, the GHG emissions could be reduced by $~ 13-35 \%$, with the highest potential reduction in the North China Plain. In conclusion, the GHG emissions and their CFs were impressively high in China's major peach-producing regions, but these GHG emissions could be substantially decreased by optimizing nutrients and irrigation management, including the rational selection of fertilizer rates and types with water-saving irrigation systems or practices (e.g., mulching) for increasing fertilizer and water use efficiency, and maintaining a sustainable peach production in China or similar countries.
\end{abstract}

Keywords: carbon mitigation; greenhouse gas emission; life cycle assessment; nitrogen fertilizer; Partial factor productivity; Prunus persica

\section{Introduction}

The rapidly increasing fruit industry over the past 20 years in China has played a positive role in promoting the development of agricultural structure and rural economic growth. The planted orchard areas and yields from 1997 to 2016 in China had been increased by 1.5 and 5.6 times, respectively, and the increase of orchard yield was closely related to increasing fertilizer input [1]. According to annual statistics in China, the amount of fertilizer used in apple and citrus orchards was averagely as high as $932 \mathrm{~kg} \mathrm{ha}^{-1}$ in 2014, which was substantially higher than in other commercial crops such as vegetables 
$\left(603 \mathrm{~kg} \mathrm{ha}^{-1}\right)$ and cotton $\left(546 \mathrm{~kg} \mathrm{ha}^{-1}\right)$ [2]. Previous study also showed that the averaged amounts of nitrogen $(\mathrm{N})$, phosphorus $\left(\mathrm{P}_{2} \mathrm{O}_{5}\right)$, and potassium $\left(\mathrm{K}_{2} \mathrm{O}\right)$ fertilizer in main peach-producing regions were as high as $734 \mathrm{~kg} \mathrm{ha}^{-1}, 492 \mathrm{~kg} \mathrm{ha}^{-1}$, and $491 \mathrm{~kg} \mathrm{ha}^{-1}$, respectively [3]. Such high fertilizer inputs in China's orchards have caused serious environmental problems such as soil acidification [4] and nutrient excess [5], and limited the sustainability of the fruit industry. However, as the population increases with the change in consumption habits, the demand for fruits will be further increased by $1.1 \%$ annually in China [6]. By facing new challenges, including limited cropland, the need of agriculture for bioenergy production, and sustainable environment, agriculture improvements will therefore have to come from sustainable intensification that makes effective use of land, water, mineral, and other resources, while not causing them harm [7]. Thus, the ecological and environmental impact of fruit orchard plantations should be addressed.

At present, global warming has become a hot topic all over the world, and the relevant "emission reduction" has become a common challenge. Fertilization and other agricultural activities have been important factors of greenhouse gas (GHG) emissions, accounting for about $24 \%$ of the total global emissions [8]. Numerous countries and organizations have begun to use the "carbon footprint (CF)" to measure GHG emissions $[9,10]$. The CF refers to the emission of GHGs directly or indirectly from a product or activity through a complete life cycle, and uses the equivalent mass of carbon dioxide $\left(\mathrm{CO}_{2}\right)$ as the unit of measurement [11]. Studies have gradually begun to quantify the agricultural carbon footprint after the emitted amount of $\mathrm{CO}_{2}$ from each link in both a crop and vegetable production system in China has been measured [12-15].

However, compared with other countries [16-18], results from a few studies on fruit productions in China indicated that carbon emissions in China's orchards were substantially high [14,15]. As a method test of CF studies on orchards in China, the CF in orchards of apple from Shaanxi province, banana from Fujian province, citrus from Hubei province, peach from Shanghai province, and pear from Hebei province was $0.24 \mathrm{~kg} \mathrm{CO}_{2}$-eq kg ${ }^{-1}, 0.27 \mathrm{~kg} \mathrm{CO}_{2}$-eq kg ${ }^{-1}, 0.14 \mathrm{~kg} \mathrm{CO}_{2}$-eq kg ${ }^{-1}, 0.37 \mathrm{~kg} \mathrm{CO}_{2}$-eq kg ${ }^{-1}$, and $0.18 \mathrm{~kg} \mathrm{CO}_{2}$-eq kg${ }^{-1}$, respectively [14]. Meanwhile, Liu et al. estimated GHG emissions in pear orchards and showed that the carbon footprint of pear orchard production links in Beijing and Liaoning province ranged from $0.06 \mathrm{~kg} \mathrm{CO}_{2}$-eq kg ${ }^{-1}$ to $0.38 \mathrm{~kg} \mathrm{CO}_{2}$-eq kg-1 [15]. These values were higher than those in apple orchards in New Zealand (0.04-0.1 $\mathrm{kg} \mathrm{CO}_{2}$-eq kg-1) [18]. Furthermore, the exiting studies on estimating the carbon footprint of orchards only focused on a farm scale or certain region, while ignoring the sample size and the sufficiency of the representatives [14,15]. It was known that the environmental impacts were different even for the same crop in the same region, which derived from differences between management practices [19]. As a result, a reliable assessment on carbon footprint has to take account into the differences within and among the regions.

China is the origin of peach, and has the largest peach fruit plantation in the world, with $34 \%$ and $37 \%$ of the global planting areas and yields, respectively [20]. The peach plantation in China is geographically divided into six major regions, namely the northeast region (NE), North China Plain (NC), northwest arid region (NW), southwest region (SW), humid Yangtze River Basin (YZ), and south China tropics (SC) [21]. Among them, NC, NW, and SW are the main production areas in China, where the total planting area and total yield in 2015 accounted for $66 \%$ and $73 \%$ of the whole of China's production areas, respectively [1]. However, the conditions of peach production, including climate, soil types, cultivars, and farmers' management practices is different among these regions in China [21]. Until now, the quantification of a carbon footprint on peach orchards at the regional scale and their comparison among different regions is rare, which limits the estimation of regional potential emission reduction and the establishment of an emission reduction method.

Based on survey data from these three major peach plantation areas in China (NC, NW, and SW), this study firstly analyzed the composition and regional differences in their carbon footprint, and then the potential of reducing the carbon emissions in each region. The current carbon footprint status of peach orchards in these three regions was then evaluated to provide better understanding of the rational distribution of the peach industry and the reduction of carbon emissions in peach orchards. 


\section{Materials and Methods}

\subsection{Study Area and Regional Characteristics}

The study areas included the NC, NW, and SW in China, which are the major peach-producing regions, but with different production conditions (Table 1). The North China Plain is the predominant peach-producing area in China with fertile loam soil, suitable temperature, and sufficient sunshine, rainfall, and irrigation. It alone produces 55\% of the total peach production in China in 2015 (Table 1). While the peach orchards in NW generally feature sandy soils and a sunny and dried climate, the orchards in SW are sited with clay soils on sloping land, and rainy sparse sunlight (Table 1). 
Table 1. The major soil type, climate characteristics, planting area and total yield in the studied three major peach plantation regions in China.

\begin{tabular}{|c|c|c|c|c|c|c|c|c|c|c|c|}
\hline \multirow{2}{*}{ Region } & \multirow{2}{*}{ Major Soil Type ${ }^{1}$} & \multirow{2}{*}{ Soil Texture ${ }^{2}$} & \multirow{2}{*}{$\operatorname{MAS}(h)^{3}$} & \multirow{2}{*}{$\operatorname{MAT}\left({ }^{\circ} \mathrm{C}\right)^{4}$} & \multirow{2}{*}{$\operatorname{MAP}(\mathrm{mm})^{5}$} & \multicolumn{3}{|c|}{ Planting Area $\left(10^{3} \mathrm{ha}^{-1}\right)^{6}$} & \multicolumn{3}{|c|}{ Yield $\left(10^{3} t\right)^{7}$} \\
\hline & & & & & & 2013 & 2014 & 2015 & 2013 & 2014 & 2015 \\
\hline North China Plain (NC) & $\begin{array}{l}\text { Hapli-Udic Argosols } \\
\text { Hapli-Ustic Argosols }\end{array}$ & Loam & $1800-2300$ & $8.0-13$ & $400-1000$ & 331 & 332 & 355 & 5503 & 7142 & 7935 \\
\hline Northwest (NW) & Loessi-Orthic Primosols & Sandy & $2400-2800$ & $1.0-16$ & $200-400$ & 56.2 & 60.2 & 65.3 & 1105 & 1157 & 1256 \\
\hline Southwest (SW) & Typic Purpli-Udic Cambosols & Clay & $1000-1400$ & $4.0-18$ & $800-1800$ & 118.2 & 127 & 141 & 987 & 1077 & 1244 \\
\hline China & & - & - & - & - & 766 & 800 & 852 & 11,924 & 12,874 & 14,288 \\
\hline
\end{tabular}

1,2,3,4,5 These data were derived from the book entitled "Peach" [21]. 3,4,5 MAS, MAT, and MAP represent mean annual sunshine, mean annual temperature, and mean annual precipitation, respectively. 6,7 These data were derived from China Agriculture Statistical Report 2016 [1]. 


\subsection{Data Sources and Processing}

Hebei and Shandong, Shaanxi and Gansu, and Sichuan and Chongqing (municipality) provinces were selected as the representative surveying locations in the NC, NW, and SW regions, respectively, because these provinces are the top two provinces of peach production in each region in China [1]. According to the method of farmer survey [22], 2-3 representative prefecture-level cities were selected from each province. Two counties or villages were randomly selected from each city or county. Ten farmers from each village were randomly selected for on-the-spot investigation. Based on the planted areas, a total of $\sim 80-120$ peach plantations or orchards were randomly surveyed from each above-mentioned province. The survey questionnaire was as follows: (1) area, variety, planting year, density, basic phenology, and yield of the last cropping season; (2) application of fertilizer and pesticide, including type, time, and amount; (3) labor costs and mechanical energy consumption for soil ploughing; and (4) electricity consumption for irrigation. In July and August of both 2016 and 2017, a total of 269 valid questionnaires were collected, including 214 from NC, 22 from NW, and 33 from SW, respectively. The collected data were saved in Excel 2010 sheets for further calculation and analysis.

A brief information from these questionnaire showed that chemical fertilizers including urea, monoammonium phosphate, potassium sulfate, and compound fertilizer $\left(\mathrm{N}-\mathrm{P}_{2} \mathrm{O}_{5}-\mathrm{K}_{2} \mathrm{O}, 15-15-15\right.$, 17-5-22, 18-9-18, and so on) were often used, while the fermented and dried manure of sheep (N-P $\mathrm{P}_{2} \mathrm{O}_{5}-\mathrm{K}_{2} \mathrm{O}, 2.01-0.49-1.32$ in average) and cattle $\left(\mathrm{N}-\mathrm{P}_{2} \mathrm{O}_{5}-\mathrm{K}_{2} \mathrm{O}, 1.67-0.43-0.95\right.$ in average) were generally used as organic fertilizer in these regions. The electricity was mainly used for irrigation by pumping the groundwater in NC and NW, and the frequency of irrigation was $\sim 3-5$ times per year, with total amounts of 300 500 $\mathrm{m}^{3} \mathrm{ha}^{-1}$. Meanwhile, in SW, the electricity was used for irrigation by pumping the rainwater from the impounding reservoir for overcoming seasonal drought. At present, there is almost no mulch usage for retaining soil moisture in peach orchards in these three regions. Diesel for soil plough is zero in SW due to the hardness of ploughing in clay soil on sloping land.

\subsection{Data Calculation}

\subsubsection{The Determination of the Boundary and Functional Units}

According to the evaluation range of the life cycle assessment method "from the cradle to the grave", the carbon emissions in this study were divided into two stages, namely, the agricultural materials stage and arable farming stage (Figure 1). The agricultural materials stage mainly included the production and transportation of fertilizers, pesticides, and diesel, and the production and transmission of electricity; meanwhile, the arable farming stage included the application of fertilizer and pesticides, the fuel consumption of mechanized management, the consumption of electricity, and so on. The functional units of this study were greenhouse gas emissions per kilogram of fresh peach fruit (carbon footprint) and per hectare.

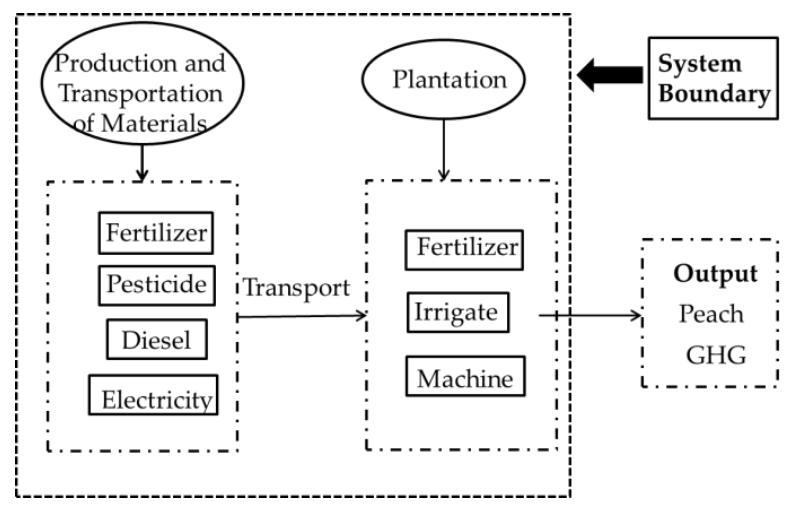

Figure 1. A system boundary of peach production in China. 


\subsubsection{Estimation of Carbon Footprint}

The formulas for the estimation of carbon footprint are as follows:

$$
\begin{gathered}
\mathrm{CEt}=\mathrm{CE}_{\mathrm{AFS}}+\mathrm{CE}_{\mathrm{AMS}} \\
\mathrm{CF}=\mathrm{CEt} / \mathrm{M}
\end{gathered}
$$

where $\mathrm{CEt}$ represents the total emissions of $\mathrm{GHG}\left(\mathrm{kg} \mathrm{CO}_{2}\right.$-eq) generated by various agricultural inputs in the peach orchard; $\mathrm{CE}_{\mathrm{AFS}}$ is the emissions of $\mathrm{N}_{2} \mathrm{O}\left(\mathrm{kg} \mathrm{CO}_{2}\right.$-eq) in arable farming stages of nitrogen $\left(\mathrm{N}\right.$, inorganic and organic) fertilizer ( $\mathrm{kg} \mathrm{CO}_{2}$-eq), including $\mathrm{N}_{2} \mathrm{O}$ emissions direct from soil, and after ammonia volatilization or soil nitrogen leaching; $\mathrm{CE}_{\mathrm{AMS}}$ means the $\mathrm{GHG}$ emissions ( $\mathrm{kg} \mathrm{CO}_{2}$-eq) in the stages of production, transportation, and investment of agricultural materials (chemical, pesticide, diesel, electricity). In addition, the GHG emissions per unit area and per unit yield are expressed as $\mathrm{CFa}\left(\mathrm{kg} \mathrm{CO}_{2}\right.$-eq ha $\left.{ }^{-1}\right)$ and $\mathrm{CFy}\left(\mathrm{kg} \mathrm{CO}_{2}\right.$-eq kg $\left.{ }^{-1}\right)$, respectively; meanwhile, $\mathrm{M}$ indicates the peach orchard planted area (ha) or yield $\left(\mathrm{kg} \mathrm{ha}^{-1}\right)$ :

$$
\begin{gathered}
\mathrm{CE}_{\mathrm{AMS}}=\sum(\mathrm{AIi} \times \mathrm{EFi}) \\
\mathrm{CE}_{\mathrm{AFS}}=\mathrm{AI}_{\mathrm{N}} \times 0.01 \times 44 / 28 \times 298+\mathrm{AI}_{\mathrm{M}} \times \mathrm{EF}_{\mathrm{M}}
\end{gathered}
$$

where Ali represents the amount of agricultural input in item $\mathrm{i}$ (fertilizer and pesticide use unit is $\mathrm{kg}$, electricity is $\mathrm{kWh}$, diesel is $\mathrm{L}$ ); and $\mathrm{EFi}$ is the amount of greenhouse gas emissions per unit or volume of agricultural material input in item i $\left(\mathrm{kg} \mathrm{CO}_{2}\right.$-eq kg ${ }^{-1}, \mathrm{~kg} \mathrm{CO}_{2}$-eq L ${ }^{-1}, \mathrm{~kg} \mathrm{CO}_{2}$-eq kWh $\left.{ }^{-1}\right)$ (Table 2); $\mathrm{AI}_{\mathrm{N}}$ is the amount of chemical $\mathrm{N}$ fertilizer input $(\mathrm{kg}) ; 0.01$ is the $\mathrm{N}_{2} \mathrm{O}$ emissions that is caused by chemical $\mathrm{N}$ fertilizer in arable farming stages $\left(\mathrm{kg} \mathrm{N}_{2} \mathrm{O} \mathrm{kg} \mathrm{N}^{-1}\right)$ [23]; 44/28 is the conversion coefficient of $\mathrm{N}_{2} \mathrm{O}-\mathrm{N}$ to $\mathrm{N}_{2} \mathrm{O} ; 298$ is the global warming potential of $\mathrm{N}_{2} \mathrm{O}$ under the 100-year scale; $\mathrm{AI}_{\mathrm{M}}$ is the amount of organic fertilizer in forms of dry weight $(\mathrm{kg})$, and $\mathrm{EF}_{\mathrm{M}}$ is the $\mathrm{N}_{2} \mathrm{O}$ emissions that is caused by organic fertilizer input, whose value is $0.223 \mathrm{~kg} \mathrm{CO}_{2}$-eq kg-1 organic fertilizer (dry weight) according to Zhang's study [24].

Table 2. Main index of greenhouse gas (GHG) emissions under different inputs. N: nitrogen (N), $\mathrm{P}$ : phosphorus (P2O5), K: potassium (K2O).

\begin{tabular}{cccc}
\hline Item & Emission Factor & Unit & References \\
\hline N Production and Transportation & 8.30 & $\mathrm{~kg} \mathrm{CO}_{2}$-eq kg & -1 \\
P Production and Transportation & 0.79 & $\mathrm{~kg} \mathrm{CO}_{2}$-eq kg & {$[24,25]$} \\
K Production and Transportation & 0.55 & $\mathrm{~kg} \mathrm{CO}_{2}-\mathrm{eq} \mathrm{kg}^{-1}$ & {$[24,25]$} \\
Pesticides & 19.1 & $\mathrm{~kg} \mathrm{CO}_{2}$-eq kg & {$[24,25]$} \\
Diesel & 3.75 & $\mathrm{~kg} \mathrm{CO}_{2}$-eq L & {$[26]$} \\
Electricity & 1.14 & $\mathrm{~kg} \mathrm{CO}_{2}$-eq kWh & {$[26]$} \\
\hline
\end{tabular}

\subsection{Relevant Definition}

\subsubsection{Partial Factor Productivity (PFP)}

Partial factor productivity (PFP) is the amount of applied fertilizer per unit fruit yield, and thus, PFP-N indicates the PFP of N fertilizer [28].

\subsubsection{Potential Emission Reduction}

According to previous study [12], if the corresponding yields and PFP-N of a peach orchard are higher than the averaged values (mean) in the same region, it is defined as a high yield and high efficiency peach orchard (HH). The reduction potential of GHG emissions per unit area or per unit yield, namely $\mathrm{CF}$, is the difference between a $\mathrm{HH}$ orchard and the average GHG emissions or $\mathrm{CF}$. Under the current plantation area, the regional potential emission reduction of GHG is the potential 
GHG emissions per area multiplied by the plantation area. The regional potential reduction of CF under the current yield level is the potential CF reduction of the region multiplied by regional total production. Among them, the plantation area and regional total production are listed in Table 1. Furthermore, a maximum potential of GHG emission reduction through optimizing fertilizer input is also projected under the condition of unchanged agricultural material input except the optimal fertilizer input, according to expert recommendation [29].

\subsection{Data Analysis and Statistics}

For the items of input and output of the three major peach plantation regions (Table 3) and their GHG emissions and CF (Figure 2), due to the abnormal distribution of some parameters in SW and $\mathrm{NW}$, non-parametric tests of independent samples were used to compare the significant difference of medians across groups by the Kruskal-Wallis one-way ANOVA in SPSS (20.0 version). The Pearson chi-square test in SPSS software was conducted to compare the significant difference in distribution of individual input to the total GHG emissions in these three regions (Figure 3). Independent student's tests in SPSS software were performed to compare the significant difference of parameters within each region (Tables 4 and 5). The White test in Stata software (14.1 version) was used to test the heteroscedasticity of linear models between the total nitrogen input and carbon footprint of the studied regions (Figure 3), and all of the data without filtering any point were used, because all of them fitted in the range of mean $\pm 3 \times \mathrm{SD}$ (standard deviation).

Table 3. Input and output of the studied three major peach plantation regions in China based on farmer survey questionnaires in 2016 and 2017. The surveying numbers for the North China Plain (NC), northwest China (NW), and southwest China (SW) were 214, 22, and 33, respectively.

\begin{tabular}{|c|c|c|c|}
\hline \multirow{2}{*}{ Item } & \multicolumn{3}{|c|}{ Surveyed Regions of Major Peach Plantation in China } \\
\hline & NC & NW & SW \\
\hline \multicolumn{4}{|c|}{ Input } \\
\hline \multicolumn{4}{|c|}{ Total Fertilizer $\left(\mathrm{kg} \mathrm{ha}^{-1}\right)$} \\
\hline $\mathrm{N}$ & $926 \pm 625(766 a)^{1}$ & $559 \pm 246(476 b)$ & $373 \pm 156(359 b)$ \\
\hline $\mathrm{P}_{2} \mathrm{O}_{5}$ & $499 \pm 297(398 a)$ & $355 \pm 208(412 \mathrm{ab})$ & $215 \pm 109(189 b)$ \\
\hline $\mathrm{K}_{2} \mathrm{O}$ & $731 \pm 449(629 a)$ & $712 \pm 497(492 a)$ & $270 \pm 91.8(280 b)$ \\
\hline \multicolumn{4}{|c|}{ Manure $\left(\mathrm{kg} \mathrm{ha}^{-1}\right)$} \\
\hline $\mathrm{N}$ & $132 \pm 182(37.4 a)$ & $51.8 \pm 151(12.3 a)$ & $73.5 \pm 66.5(69.3 a)$ \\
\hline $\mathrm{P}_{2} \mathrm{O}_{5}$ & $54.6 \pm 67(24.8 a)$ & $37.0 \pm 84.4(12.0 \mathrm{a})$ & $38.1 \pm 32.9(39.6 a)$ \\
\hline $\mathrm{K}_{2} \mathrm{O}$ & $92.2 \pm 124(30.0 a)$ & $44.4 \pm 113(12.8 \mathrm{a})$ & $55.2 \pm 46.4(59.4 a)$ \\
\hline \multicolumn{4}{|c|}{ Chemical Fertilizer $\left(\mathrm{kg} \mathrm{ha}^{-1}\right)$} \\
\hline $\mathrm{N}$ & $794 \pm 551(630 a)$ & $507 \pm 229(432 b)$ & $300 \pm 128(291 b)$ \\
\hline $\mathrm{P}_{2} \mathrm{O}_{5}$ & $444 \pm 392(336 a)$ & $319 \pm 176(393 a b)$ & $178 \pm 107(135 b)$ \\
\hline $\mathrm{K}_{2} \mathrm{O}$ & $640 \pm 401(550 a)$ & $668 \pm 506(445 a)$ & $216 \pm 95.0(293 b)$ \\
\hline Pesticide $\left(\mathrm{kg} \mathrm{ha}^{-1}\right)$ & $37.2 \pm 43.6(20.0 a)$ & $13.4 \pm 5.50(11.6 b)$ & $10.6 \pm 11.6(9.0 b)$ \\
\hline Electricity $\left(\mathrm{kWh} \mathrm{ha}^{-1}\right)$ & $1219 \pm 976(990 b)$ & $1827 \pm 527(1600 a)$ & $91.8 \pm 18.7(90.0 \mathrm{c})$ \\
\hline Diesel $\left(\mathrm{L} \mathrm{ha}^{-1}\right)$ & $19.6 \pm 43.9(15.0 a)$ & $14.7 \pm 3.20(15.0 b)$ & $0^{2}$ \\
\hline \multicolumn{4}{|c|}{ Output } \\
\hline Yield (t ha $\left.{ }^{-1}\right)$ & $35.7 \pm 12.7(37.5 a)$ & $37.8 \pm 3.60(37.5 a)$ & $31.4 \pm 11.2(30.0 a)$ \\
\hline
\end{tabular}

${ }^{1}$ Data were represented by mean \pm standard deviation with the median in parentheses. Different letters after the medians in each row indicated significant differences among the three regions tested by the method of Kruskal-Wallis one-way ANOVA at $p<0.05 .{ }^{2}$ There was no diesel consumption in SW China according to the farmer survey. 

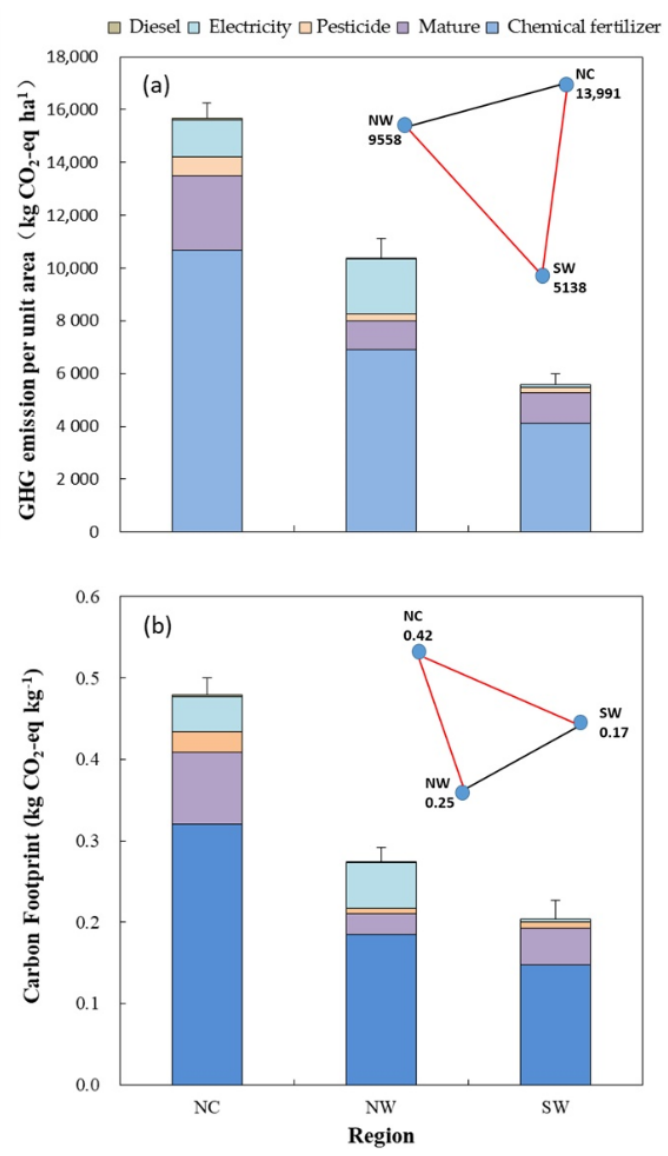

Figure 2. Greenhouse gas emissions (a) and carbon footprint (b) of three major peach plantation regions in China based on farmer survey questionnaires conducted in 2016 and 2017. The surveying numbers for the North China Plain (NC), northwest China (NW), and southwest China (SW) were 214, 22, and 33, respectively. The bar on each column indicated the standard deviation of the datasets. The triangle in each figure indicated the median of these datasets, where the red line showed significant difference between the two independent datasets at $p<0.05$, and where the black lines showed no significant differences by the Kruskal-Wallis one-way ANOVA.

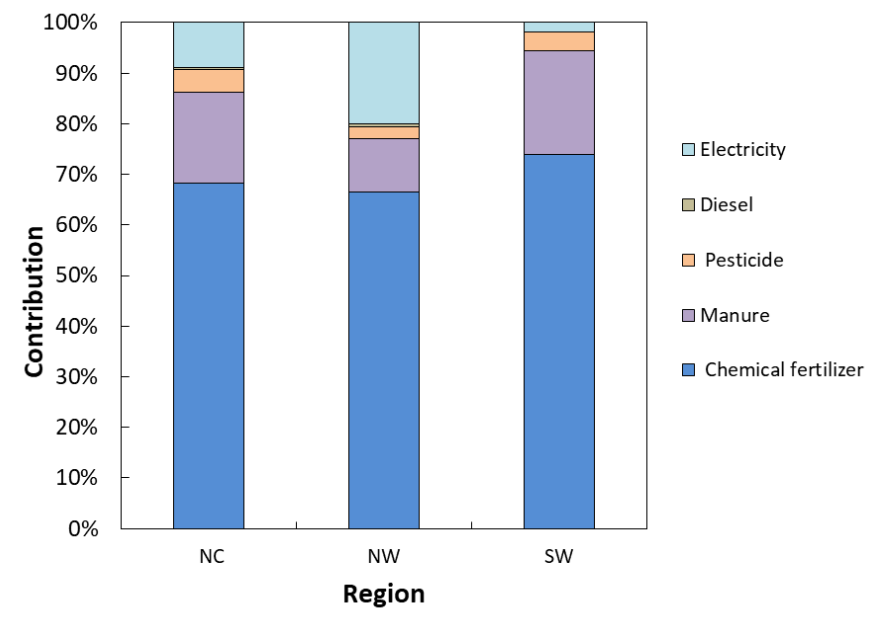

Figure 3. Contribution of individual input to the carbon footprint in three major peach plantation regions in China based on farmer survey questionnaires in 2016 and 2017. The surveying numbers for the North China Plain (NC), northwest China (NW), and southwest China (SW) were 214, 22, and 33 , respectively. 
Table 4. Comparison of the input source contribution between the high yield and high partial factor productivity of nitrogen (PFP-N) in peach orchards (HH) and the regional mean peach orchard (mean). The data in the table are all derived from the calculation, grouping, and analysis of farmer survey questionnaires in the North China Plain (NC), northwest China (NW), and southwest China (SW) in 2016 and 2017.

\begin{tabular}{|c|c|c|c|c|c|c|c|c|c|c|c|c|}
\hline \multirow{3}{*}{ Item } & \multicolumn{6}{|c|}{ GHG Emissions (kg CO ${ }_{2}$-eq ha $\left.{ }^{-1}\right)$} & \multicolumn{6}{|c|}{ Carbon Footprint $\left(\mathrm{kg} \mathrm{CO}_{2}-\mathrm{eq} \mathrm{kg}{ }^{-1}\right)$} \\
\hline & \multicolumn{2}{|l|}{ NC } & \multicolumn{2}{|c|}{ NW } & \multicolumn{2}{|c|}{ SW } & \multicolumn{2}{|c|}{ NC } & \multicolumn{2}{|c|}{ NW } & \multicolumn{2}{|c|}{ SW } \\
\hline & HH $(27 \%)^{1}$ & Mean & НH (41\%) & Mean & HH (30\%) & Mean & HH & Mean & HH & Mean & HH & Mean \\
\hline N Fertilizer & $6319 b^{2}$ & $10,303 a$ & $4537 \mathrm{~b}$ & $6585 a$ & $3293 a$ & $3893 a$ & $0.138 b$ & $0.309 a$ & $0.116 \mathrm{~b}$ & $0.176 a$ & $0.075 \mathrm{~b}$ & $0.139 a$ \\
\hline P Fertilizer & $219 b$ & $348 a$ & $171 \mathrm{a}$ & $261 \mathrm{a}$ & $149 a$ & $178 \mathrm{a}$ & $0.005 b$ & $0.011 \mathrm{a}$ & $0.004 a$ & $0.007 \mathrm{a}$ & $0.003 b$ & $0.007 a$ \\
\hline K Fertilizer & $32.6 a$ & $39.0 \mathrm{a}$ & $34.5 \mathrm{a}$ & $52.2 \mathrm{a}$ & $51.3 a$ & $52.2 \mathrm{a}$ & $0.0007 \mathrm{~b}$ & $0.001 \mathrm{a}$ & $0.0009 a$ & $0.001 \mathrm{a}$ & $0.001 \mathrm{~b}$ & $0.002 \mathrm{a}$ \\
\hline Manure & $1860 a$ & $2806 a$ & $461 \mathrm{a}$ & $1097 a$ & $947 a$ & $1150 a$ & $0.041 \mathrm{a}$ & $0.088 \mathrm{a}$ & $0.012 \mathrm{a}$ & $0.030 \mathrm{a}$ & $0.024 \mathrm{a}$ & $0.050 \mathrm{a}$ \\
\hline Pesticide & $550 \mathrm{a}$ & $711 a$ & $292 a$ & $255 a$ & $306 a$ & $202 a$ & $0.013 a$ & $0.025 \mathrm{a}$ & $0.008 \mathrm{a}$ & $0.010 \mathrm{a}$ & $0.007 \mathrm{a}$ & $0.007 \mathrm{a}$ \\
\hline Electricity & $1164 a$ & $1388 \mathrm{a}$ & $2010 a$ & $2079 a$ & $106 a$ & $105 a$ & $0.026 \mathrm{~b}$ & $0.045 \mathrm{a}$ & 0.051 & $0.060 \mathrm{a}$ & $0.002 a$ & $0.004 a$ \\
\hline Diesel & $71.2 \mathrm{a}$ & $73.6 \mathrm{a}$ & $58.5 \mathrm{a}$ & $55.3 a$ & - & - & $0.002 \mathrm{a}$ & $0.002 \mathrm{a}$ & $0.001 \mathrm{~b}$ & $0.002 \mathrm{a}$ & - & - \\
\hline Total & $10,216 b$ & $15,668 \mathrm{a}$ & $7564 b$ & $10,386 a$ & $4853 a$ & $5580 a$ & $0.225 b$ & $0.480 \mathrm{a}$ & $0.193 b$ & $0.270 \mathrm{a}$ & $0.113 b$ & $0.200 \mathrm{a}$ \\
\hline Potential emission reduced & \multicolumn{2}{|l|}{5452} & \multicolumn{2}{|c|}{2822} & \multicolumn{2}{|c|}{727} & \multicolumn{2}{|c|}{0.255} & \multicolumn{2}{|c|}{0.077} & \multicolumn{2}{|c|}{0.087} \\
\hline
\end{tabular}

${ }^{1}$ Values in parenthesis indicated the percentage of $\mathrm{HH}$ orchards in the total orchards. ${ }^{2}$ Different letters within each region indicated significant differences $(p<0.05)$ in GHG emissions or carbon footprints (CF) between the regional mean input orchard and the HH orchard. 
Table 5. Comparison of the total fertilizer (chemical and manure fertilizer) inputs and yield outputs between the high yield and high PFP-N (HH) peach orchard and the regional mean level peach orchard (mean). Data in the table are all derived from the calculation, grouping, and analysis of the farmer survey questionnaires in the North China Plain (NC), northwest China (NW), and southwest China (SW) in 2016 and 2017.

\begin{tabular}{ccccccc}
\hline \multirow{2}{*}{ Item } & \multicolumn{2}{c}{ NC } & \multicolumn{2}{c}{ NW } & \multicolumn{2}{c}{ SW } \\
\cline { 2 - 6 } & HH & Mean & HH & Mean & HH & Mean \\
\hline Chemical Fertilizer: $\mathrm{N}\left(\mathrm{kg} \mathrm{ha}^{-1}\right)$ & $481 \mathrm{~b}^{1}$ & $794 \mathrm{a}$ & $350 \mathrm{~b}$ & $508 \mathrm{a}$ & $254 \mathrm{a}$ & $300 \mathrm{a}$ \\
Chemical Fertilizer: $\mathrm{P}_{2} \mathrm{O}_{5}\left(\mathrm{~kg} \mathrm{ha}^{-1}\right)$ & $279 \mathrm{~b}$ & $444 \mathrm{a}$ & $204 \mathrm{a}$ & $319 \mathrm{a}$ & $141 \mathrm{a}$ & $178 \mathrm{a}$ \\
Chemical Fertilizer: $\mathrm{K}_{2} \mathrm{O}\left(\mathrm{kg} \mathrm{ha}^{-1}\right)$ & $524 \mathrm{~b}$ & $640 \mathrm{a}$ & $366 \mathrm{a}$ & $668 \mathrm{a}$ & $201 \mathrm{a}$ & $216 \mathrm{a}$ \\
Manure: $\mathrm{N}\left(\mathrm{kg} \mathrm{ha}^{-1}\right)$ & $73 \mathrm{~b}$ & $132 \mathrm{a}$ & $26 \mathrm{a}$ & $52 \mathrm{a}$ & $52 \mathrm{a}$ & $74 \mathrm{a}$ \\
Manure: $\mathrm{P}_{2} \mathrm{O}_{5}\left(\mathrm{~kg} \mathrm{ha}^{-1}\right)$ & $36 \mathrm{a}$ & $55 \mathrm{a}$ & $25 \mathrm{a}$ & $37 \mathrm{a}$ & $27 \mathrm{a}$ & $38 \mathrm{a}$ \\
Manure: $\mathrm{K}_{2} \mathrm{O}\left(\mathrm{kg} \mathrm{ha}^{-1}\right)$ & $53 \mathrm{~b}$ & $92 \mathrm{a}$ & $27 \mathrm{a}$ & $44 \mathrm{a}$ & $39 \mathrm{a}$ & $55 \mathrm{a}$ \\
Yield $\left(\mathrm{t} \mathrm{ha}^{-1}\right)$ & $46 \mathrm{a}$ & $36 \mathrm{~b}$ & $39 \mathrm{a}$ & $38 \mathrm{a}$ & $44 \mathrm{a}$ & $32 \mathrm{~b}$ \\
\hline
\end{tabular}

${ }^{1}$ Different letters within each region indicate significant difference $(p<0.05)$ in compared items between the regional mean input orchard and the $\mathrm{HH}$ orchard.

\section{Results}

\subsection{Input and Output in Peach Production in Major Regions}

Analyses of the surveyed questionnaire data showed that there were significant differences in agriculture material input among the three regions according to the median test of these datasets (Table 3). The total amount of applied nitrogen $(\mathrm{N})$, phosphorus $\left(\mathrm{P}_{2} \mathrm{O}_{5}\right)$, and potassium $\left(\mathrm{K}_{2} \mathrm{O}\right)$ fertilizer was highest in NC, and only $40 \%, 43 \%$, and $40 \%$ of these NC's inputs were respectively seen in SW. However, the respective proportion of organic N, P, and K was highest in SW (20\%, 20\%, and 21\%), higher in NC $(16 \%, 15 \%$, and $14 \%)$ and lowest in NW $(7 \%, 9 \%$, and $7 \%)$. The inputs of pesticides were highest in NC $\left(37.2 \mathrm{~kg} \mathrm{ha}^{-1}\right)$, and $36 \%$ and $29 \%$ of these NC's inputs were observed in NW and SW, respectively; the consumption of electricity for irrigation was highest in NW (1827 $\left.\mathrm{kWh} \mathrm{ha}^{-1}\right)$, higher in NC (1219 $\left.\mathrm{kWh} \mathrm{ha}^{-1}\right)$, and lowest in SW $\left(<100 \mathrm{kWh} \mathrm{ha}^{-1}\right)$; and the diesel consumption in NC and NW was similar (19.6 $\mathrm{L} \mathrm{ha}^{-1}$ and $14.7 \mathrm{~L} \mathrm{ha}^{-1}$ ), while there was no diesel consumption in SW. The yield output was highest in NW $\left(37.8 \mathrm{t} \mathrm{ha}^{-1}\right)$, higher in NC ( $\left.35.7 \mathrm{t} \mathrm{ha}^{-1}\right)$, and lowest in SW (31.4 tha $\left.{ }^{-1}\right)$.

\subsection{Contributions of Individual Input to GHG Emissions}

Among the three regions, the averaged GHG emissions and corresponding CF were highest in NC $\left(15,668 \mathrm{~kg} \mathrm{CO}_{2}\right.$-eq ha ${ }^{-1}$ and $0.48 \mathrm{~kg} \mathrm{CO}_{2}$-eq kg $\left.{ }^{-1}\right)$, higher in NW $\left(10,386 \mathrm{~kg} \mathrm{CO}_{2}\right.$-eq ha ${ }^{-1}$ and $0.27 \mathrm{~kg} \mathrm{CO}_{2}$-eq kg ${ }^{-1}$ ), and lowest in SW $\left(580 \mathrm{~kg} \mathrm{CO}_{2}\right.$-eq ha ${ }^{-1}$ and $0.20 \mathrm{~kg} \mathrm{CO}_{2}$-eq kg$\left.{ }^{-1}\right)$ (Figure 2). The median test also showed that GHG emissions in both NC and NW were significantly higher than that in SW, while there were no significant differences between NC and NW; the CF in both SW and NW was significantly lower than that in NC (Figure 2).

The contribution factor analysis showed that fertilizers were the primary emission factor for GHG emissions (Figure 3), and the N fertilizer contributed $66 \%, 68 \%$, and $70 \%$ of these GHG emissions in NC, NW, and SW, respectively. Meanwhile, the electricity was the second largest contributor, which accounted for $20 \%, 9 \%$, and $2 \%$ in NW, NC, and SW, respectively; meanwhile, both the pesticides and diesel contributed less than $5 \%$ in all these three regions, except there was no diesel contribution in SW. Results from the Pearson chi-square test showed that the contribution factors, including chemical fertilizer $(p=0.036)$, manure $(p<0.01)$, diesel $(p<0.01)$, and electricity $(p<0.01)$, were significant differences among the three regions. Furthermore, the input of $\mathrm{N}$ fertilizer was significantly and linearly correlated with CF in these three regions, particularly in NC and NW (Figure 4). In addition, the White test showed that the heteroscedasticity of the linear models in NC $(p=0.067)$, NW $(p=0.436)$, 
and SW ( $p=0.783$ ) was non-existent, indicating the other missing independent factors such as pesticide, diesel, and so on.

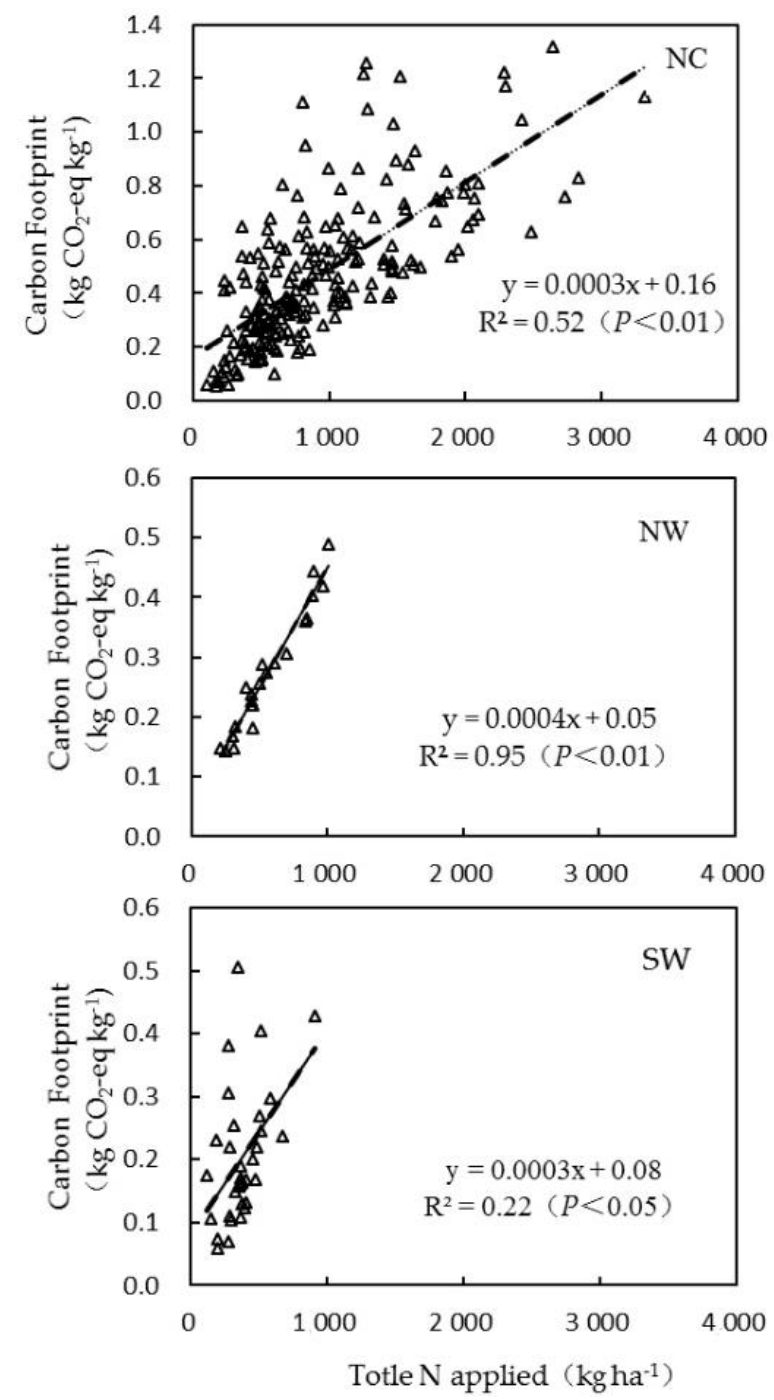

Figure 4. Correlations between total nitrogen $(\mathrm{N})$ application (including chemical fertilizers and manure) and carbon footprint in three major peach plantation regions in China. Data in the figure were all derived from the calculation and analysis of farmer questionnaires in 2016 and 2017. The surveying numbers for the North China Plain (NC), northwest China (NW), and southwest China (SW) were 214, 22 , and 33 , respectively.

\subsection{Potential in Carbon Emission Reduction in Typical Peach Orchards in China}

In the three major peach plantation regions, $\mathrm{HH}$ (high yield and high PFP-N) peach orchards accounted for $27 \%, 41 \%$, and $30 \%$ of all of the orchards in NC, NW, and SW, respectively (Table 4). Compared with regional values, the averaged GHG emissions of $\mathrm{HH}$ orchards in NC, NW, and SW were reduced by $35 \%, 27 \%$, and $13 \%$, and the mean CF were reduced by $53 \%, 30 \%$, and $45 \%$, respectively. The differences in the carbon emission intensity of fertilizers between a $\mathrm{HH}$ orchard and other orchards resulted in a substantial reduction of GHG emissions in the HH orchard, especially chemical $\mathrm{N}$ fertilizers, which had significant influence on the GHG emissions (Table 4). Combined with the total plantation areas of peach orchards in these three regions (Table 1), the total potential emission reduction was largest in $\mathrm{NC}\left(1936 \times 10^{3} \mathrm{t} \mathrm{CO}_{2}\right.$-eq $)$, higher in $\mathrm{NW}\left(184 \times 10^{3} \mathrm{tCO}_{2}\right.$-eq), and lowest in $\mathrm{SW}\left(102 \times 10^{3} \mathrm{tCO}_{2}\right.$-eq). If the total yields of these three regions remained unchanged, the total 
potential reduced emissions were also greatest in $\mathrm{NC}\left(1960 \times 10^{3} \mathrm{tCO}_{2}\right.$-eq $)$, which was 19.3 times and 17.3 times that of those in NW $\left(102 \times 10^{3} \mathrm{tCO}_{2}\right.$-eq $)$ and SW $\left(113 \times 10^{3} \mathrm{tCO}_{2}\right.$-eq $)$, respectively (Figure 5).

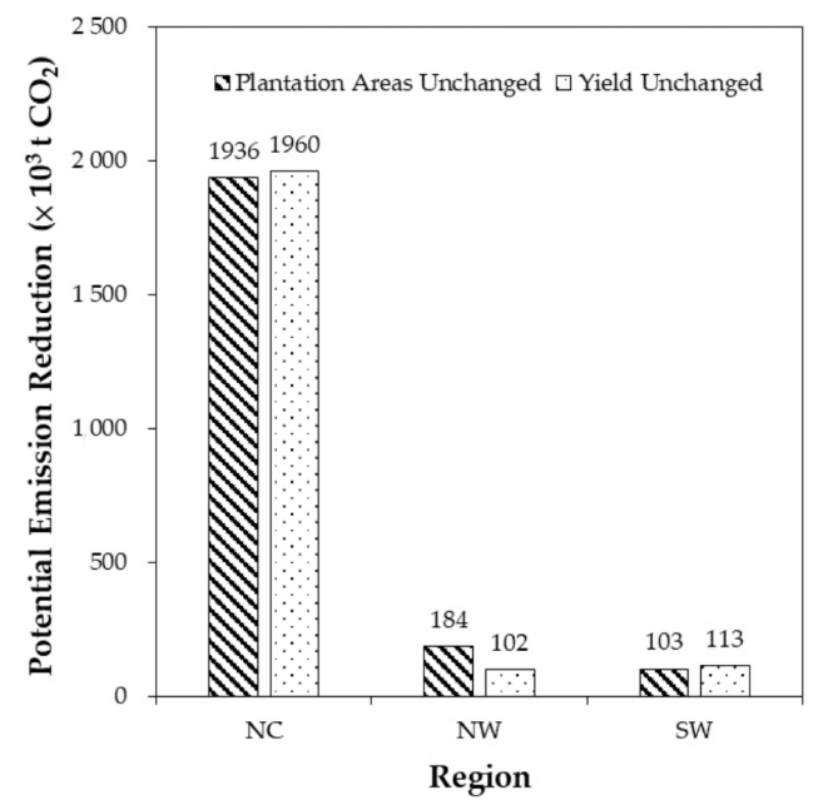

Figure 5. Potential emission reductions in the studied three major peach plantation regions in China under the condition of unchanged plantation areas or yields. Data in the figure were all derived from the grouping, calculation, and analysis of farmer survey questionnaires in the North China Plain (NC), northwest China (NW), and southwest China (SW).

\section{Discussion}

In this study, both the total GHG emissions and the differences in the structure of GHG emissions were larger among the regions (Figure 2). Fertilizer inputs were the main reason for the difference in GHG emissions (Table 3). For example, NC had a higher amount of fertilizer input, especially $\mathrm{N}$ fertilizer, which was 1.7 times and 2.5 times greater than that in NW and SW, respectively. The differences in producing CF were derived from the fertilizer inputs, planted variety, and yields [19]. Farmers usually apply fertilizers based on the growth stage of crop variety, which directly determines its achievable yield [21]. There is a large variation in climate and soil conditions in China (Table 1); thus, the dominant varieties of peach plantation in the three regions are also different. Therefore, the amount, times of fertilization, and yield are also different. For example, more than $80 \%$ of the peach orchards in NC are mainly middle and late ripened varieties, and $\sim 3-4$ times of fertilization are applied annually [3]. Inversely, the early ripened varieties are generally grown in SW, with $\sim 2-3$ times the amount of fertilizations annually [3]. This would be one reason that farmers in NC use a higher amount of fertilizer input. On the other hand, the peach industry in NC is at the forefront of the country, so the farmers are driven by economic incentives and invest fertilizers heavily to ensure high yield [3,21]. In SW, most of the peach orchards are located in sloping lands with small scales, where it is not convenient for mechanized management and fertilizer application. Thus, there is no diesel consumption for soil ploughing, and the fertilization rate is lowest (Table 3). In addition, the production modes are small farmers coexisting with the large-scale and intensive peach orchards in SW, with large difference in fertilizer use, especially regarding the proportion of organic nutrients (Table 3). Manure and chemical fertilizer also have huge differences in carbon footprint factors (Equation 4), all together leading to a weakened correlation between the total amount of nitrogen fertilizer and carbon footprint in SW (Figure 4). Compared with previous studies, the GHG emissions of peach orchards was higher in NC and NW (this study) than in Shanghai (5900 $\mathrm{kg} \mathrm{CO}_{2}$-eq ha ${ }^{-1}$ ) [14]. This was 
mainly due to a larger amount of fertilizer applied in these two regions. For example, the $\mathrm{N}$ fertilization was 3.1 times and 1.8 times greater in NC and NW than in Shanghai's peach orchards, respectively (Table 3). On average, the CFs in these three regions $\left(0.05-1.79 \mathrm{~kg} \mathrm{CO}_{2}-\mathrm{eq} \mathrm{kg}^{-1}\right)$ were similar to the peach orchard in Shanghai (0.37 $\mathrm{kg} \mathrm{CO}_{2}$-eq kg ${ }^{-1}$ ) [14] and Spain $\left(0.16-0.37 \mathrm{~kg} \mathrm{CO}_{2}\right.$-eq kg ${ }^{-1}$ ) [30], but were higher than that in China's pears orchards $\left(0.12-0.27\right.$ and $0.06-0.38 \mathrm{~kg} \mathrm{CO}_{2}$-eq kg $\left.{ }^{-1}[15,31]\right)$ and citrus orchards $\left(0.14 \mathrm{~kg} \mathrm{CO}_{2}\right.$-eq kg $\left.{ }^{-1}\right)$ [14]. These results indicated that GHG emissions in the peach orchards were even higher than those in other types of orchards. The main reason for both the differences in GHG emissions and CFs in the same region was thus derived from the fertilization input and yield output [19]. For instance, $\mathrm{N}$ fertilizer inputs in the $\mathrm{HH}$ orchard were significantly lower compared to the averaged regional inputs (Table 5). Compared to the averaged regional level, the $\mathrm{CF}$ was lower in the HH peach orchard due to lower GHG emissions with a higher peach yield. As a result, a reduced emission of both the regional GHG and CF potential appeared highest in NC, followed by NW and SW, under the current regional total plantation area and yield level (Figure 5).

The future development of fruit industries will be gradually focused on the dominant plantation regions [32]. NC, as the traditional dominant fruit production area with its coordinated light, heat, geography, and transportation conditions, is still the most important peach-producing area in China (Table 1). Moreover, results from this study showed a substantial potential in GHG emission reduction in NC (Figure 5). With the proposal of the Chinese National Energy Conservation and Emission Reduction Strategy and the need of green agriculture development $[19,33]$, it is imperative to optimize the plantation management and then cut down the GHG emissions in the peach orchards of NC. In this study, the averaged $\mathrm{N}$ fertilization in NC was $926 \mathrm{~kg} \mathrm{ha}^{-1}$, which was close to previous studies $[5,34,35]$, but greater than the rate of $150-200 \mathrm{~kg} \mathrm{ha}^{-1}$ that was recommended by extension experts under the target yield of $40 \mathrm{tha}^{-1}$ on a medium fertility orchard [29]. Decreasing $\mathrm{N}$ fertilizer inputs could significantly reduce the corresponding GHG emissions and $\mathrm{CF}$, since $\mathrm{N}$ fertilizer inputs are significantly positively correlated to $\mathrm{CF}$ (Figure 4, Table 5). For example, with a $33.5 \%$ reduction of $\mathrm{N}$ input in a peach orchard, the yield was even increased by $27.5 \%$, suggesting that an external $\mathrm{N}$ supply with a synchronized absorption could be an effective way to increase peach yields [36] and reduce CF at the same time [33]. In this study, the average yield of 214 peach orchards in NC was only $35.7 \mathrm{t} \mathrm{ha}^{-1}$; however, the reported attainable yield in the same region was from $48 \mathrm{t} \mathrm{ha}^{-1}$ to $55 \mathrm{tha}^{-1}[36,37]$. Thus, the peach orchards in NC could have considerable potential to increasing their productivity. Moreover, the application of highly efficient and environmentally friendly fertilizer types could also have an impact on GHG emissions reduction. Studies have shown that the application of urea, rather than ammonium nitrate calcium, increased soil $\mathrm{N}_{2} \mathrm{O}$ emissions in both peach and apple orchards [38]. This was also true for GHG emission decrease when controlled-release fertilizer was applied [39]. Thus, an optimal management such as the control of both amount and type of $\mathrm{N}$-fertilizer could obtain high yields with less environmental costs concurrently in peach orchards or other cropping systems in China [19]. As a projection in the future, GHGs emission in NC could be further decreased from $15,668 \mathrm{~kg} \mathrm{CO}_{2}$-eq ha ${ }^{-1}$ (current farmers' status) to $10,216 \mathrm{~kg} \mathrm{CO}_{2}$-eq ha ${ }^{-1}$ (farmer based $\mathrm{HH}$ orchards), and to $4979 \mathrm{~kg} \mathrm{CO}_{2}$-eq ha ${ }^{-1}$ (optimal nutrient management by extension expert in China); similar trends are also shown for the CFs (Figure 6).

Under the scenario with an optimal nutrient management (Figure 6), the contribution of fertilizer, pesticide, electricity, and diesel to the CF is $56 \%, 14 \%, 28 \%$, and $1.0 \%$ for NC, $53 \%, 5 \%, 39 \%$, and $1 \%$ in $\mathrm{NW}$, and $90 \%, 6 \%, 3 \%$, and $0 \%$ in SW (data not shown), respectively. It is clearly shown that electricity is another noticeable contributor in the humid regions, and especially in the arid NW (Figure 3), and its contribution to GHG emissions becomes of importance when the farmers' fertilization practice is becoming rationale [19]. In these regions, electricity consumption was mainly for irrigation by electricity-driven pumps, which had generated a great deal of $\mathrm{CO}_{2}$ emissions [40]. As a solution, it is of great significance to renovate irrigation systems and improve water and fertilizer use efficiency in the peach orchard, since the CF could be thus decreased by water-saving irrigation [40]. 

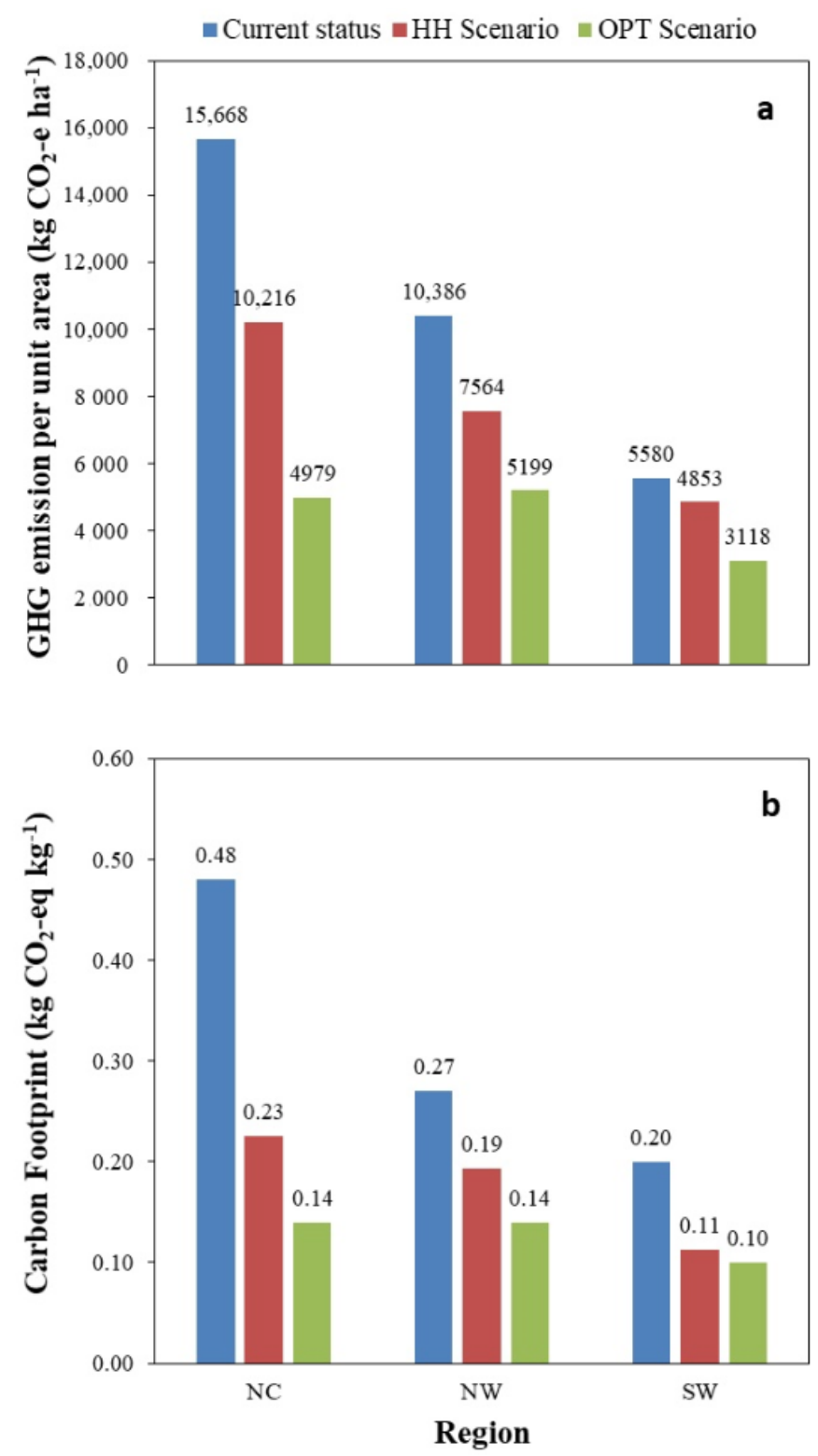

Figure 6. Scenarios analyses of greenhouse gas emissions (a) and carbon footprint (b) in the studied three major peach production regions in China. Data under current status and high yield and high PFP-N scenarios (HH scenario) are all derived from the calculation, grouping, and analysis of the farmer survey questionnaires in the North China Plain (NC), northwest China (NW), and southwest China (SW) in 2016 and 2017, which are also shown in Table 4. The scenario with optimal nutrient management (OPT scenario) is projected basing on the current input level of pesticide, electricity, and diesel (Table 1), but with the recommended upper rates of $\mathrm{N}\left(200 \mathrm{~kg} \mathrm{~N} \mathrm{ha}^{-1}\right), \mathrm{P}\left(100 \mathrm{~kg} \mathrm{P}_{2} \mathrm{O}_{5} \mathrm{ha}^{-1}\right)$, and $\mathrm{K}\left(300 \mathrm{~kg} \mathrm{~K}_{2} \mathrm{O} \mathrm{ha}^{-1}\right)$ fertilizer in China [29].

\section{Conclusions}

In these three typical peach plantation regions (NC, NW, and SW) in China, the emissions of GHG and corresponding CF were highest in NC, followed by NW and SW. On average, the GHG emissions or CFs were 1.5 times or 1.8 times and 2.8 times or 2.5 times greater in NC than in NW and $\mathrm{SW}$, respectively. The CFs significantly and positively correlated to $\mathrm{N}$ inputs, and the contribution of $\mathrm{N}$ fertilizer as the first contributor in NC, NW, and SW was $66 \%, 68 \%$, and $70 \%$ of the emissions of GHG, respectively. In addition, the electricity consumption for irrigation was the second contributor to the emissions of GHG, especially in NW, while the pesticide and diesel contributed the lowest 
$(<5 \%)$ to the GHG emissions in these three peach plantation regions. The GHG emissions or CFs were decreased by $13-35 \%$ or $30-53 \%$ in the $\mathrm{HH}$ peach orchard when compared with the regional averaged levels. As a projection of the future scenario, GHG emissions could be further decreased by integrative nutrient and irrigation management, including the rational selection of fertilizer rates and types with water-saving irrigation system or practices (e.g., mulching), while increasing fertilizer and water use efficiency and maintaining a sustainable peach production.

Author Contributions: C.G. and Y.Z. designed the survey questionnaire with the assistance by Y.L. and J.W.; C.G. analyzed the survey data and wrote the manuscript with Y.Z. and X.H.; X.W. was the first author's advisor, and was responsible for providing methodology of Life Cycle Assessment; W.Z. provided the emission factors and calculation formula template; X.H., X.S. and X.C. assisted in outlining and amending the manuscript.

Funding: This research was funded by the National Key Research and Development Project of China (2016YFD0800304), the National Key Technology Research and Development Program (2015BAD06B04), the Fundamental Research Funds for the Central Universities (2362015xk06, XDJK2013C065 and 20710922).

Conflicts of Interest: The authors declare no conflicts of interest.

\section{References}

1. Ministry of Agriculture of the People's Republic of China. China Agriculture Statistical Report 2016; China Agricultural Press: Beijing, China, 2017; pp. 65-68.

2. Hou, M.Y.; Zhang, L.; Wang, Z.W.; Yang, D.L.; Wang, L.L.; Xiu, W.M.; Zhao, J.N. Estimation of fertilizer usage from main crops in China. J. Agric. Res. Environ. 2017, 34, 360-367.

3. Yan, Z.J. Construction and Application of Nutrient Management System for Peach Orchard at Different Regional Levels (NMSP). Master's Thesis, Chinese Agricultural University, Beijing, China, 2010.

4. Bhattachayya, R.; Ghosh, B.N.; Mishra, P.K.; Mandal, B.; Rao, C.S.; Sarkar, D.; Das, K.; Anil, K.S.; Lalitha, M.; Hati, K.M.; et al. Soil degradation in India: Challenges and potential solutions. Sustainability 2015, 7, 3528-3570. [CrossRef]

5. Lu, S.C.; Yan, Z.J.; Chen, Q.; Zhang, F.S. Evaluation of conventional nitrogen and phosphorus fertilization and potential environmental risk in intensive orchard of North China. J. Plant. Nutr. 2012, 10, 1509-1525. [CrossRef]

6. Xu, S.W.; Li, G.Q.; Li, Z.M. China agricultural outlook for 2015-2024 based on China Agricultural Monitoring and Early-warning System (CAMES). J. Integr. Agric. 2015, 14, 1889-1902. [CrossRef]

7. Popp, J.; Lakner, Z.; Harangi-Rákos, M.; Fári, M. The effect of bioenergy expansion: Food, energy and environment. Renew. Sustain. Energy Rev. 2014, 32, 559-578. [CrossRef]

8. IPCC. Climate Change 2014: Mitigation of Climate Change; Contribution of Working Group III to the Fifth Assessment Report of the Intergovernmental Panel on Climate Change; IPCC: Geneva, Switzerland, 2014.

9. Johnson, J.M.; Franzluebbers, A.J.; Weyers, S.L.; Reicosky, D.C. Agricultural opportunities to mitigate greenhouse gas emissions. Environ. Pollut. 2007, 150, 107-124. [CrossRef] [PubMed]

10. Pérez-Neira, D.; Grollmus-Venegas, A. Life-cycle energy assessment and carbon footprint of peri-urban horticulture. A comparative case study of local food systems in Spain. Landsc. Urban Plan. 2018, 172, 60-68. [CrossRef]

11. Strutt, J.; Wilson, S.; Shorney-Darby, H.; Shaw, A.; Byers, A. Assessing the carbon footprint of water production. J. Am. Water. Works Assoc. 2008, 100, 80-99. [CrossRef]

12. Wang, Z.B.; Wang, M.; Chen, F. Carbon footprint analysis of crop production in North China Plain. Sci. Agric. Sin. 2015, 48, 83-92.

13. Zhang, W.S.; He, X.M.; Zhang, Z.D.; Gong, S.; Zhang, Q.; Zhang, W.; Liu, D.Y.; Zou, C.Q.; Chen, X.P. Carbon footprint assessment for irrigated and rainfed maize (Zea mays L.) production on the Loess Plateau of China. Biosyst. Eng. 2018, 167, 75-86. [CrossRef]

14. Yan, M.; Cheng, K.; Yue, Q.; Yan, Y.; Ress, R.M.; Pan, G.X. Farm and product carbon footprints of China's fruit production-Life cycle inventory of representative orchards of five major fruits. Environ. Sci. Pollut. Res. 2015, 23, 4681-4691. [CrossRef] [PubMed]

15. Liu, Y.; Langer, V.; Høgh-Jensen, H.; Egelyng, H. Life Cycle Assessment of fossil energy use and greenhouse gas emissions in Chinese pear production. J. Clean. Prod. 2010, 18, 1423-1430. [CrossRef] 
16. Soode-Schimonsky, E.; Richter, K.; Weber-Blaschke, G. Product environmental footprint of strawberries: Case studies in Estonia and Germany. J. Environ. Manag. 2017, 203, 564-577. [CrossRef] [PubMed]

17. Stoessel, F.; Juraske, R.; Pfister, S.; Hellweg, S. Life cycle inventory and carbon and water footprint of fruits and vegetables: Application to a Swiss retailer. Environ. Sci. Technol. 2012, 46, 3253-3262. [CrossRef] [PubMed]

18. Goossens, Y.; Geeraerd, A.; Keulemans, W.; Annaert, B.; Mathijs, E.; De Tavernier, J. Life cycle assessment (LCA) for apple orchard production systems including low and high productive years in conventional, integrated and organic farms. Agric. Syst. 2017, 153, 81-93. [CrossRef]

19. Chen, X.P.; Cui, Z.L.; Fan, M.S.; Vitousek, P.; Zhao, M.; Ma, W.Q.; Wang, Z.L.; Zhang, W.J.; Yan, X.Y.; Yang, J.C.; et al. Producing more grain with lower environmental costs. Nature 2014, 514, 486-489. [CrossRef] [PubMed]

20. Food and Agriculture Organization of the United Nations. FAOSTAT Database; Food and Agriculture Organization of the United Nations: Rome, Italy, 2016.

21. Li, S.H. Peach; China Agriculture Press: Beijing, China, 2013.

22. Wu, L.; Chen, X.; Cui, Z.; Zhang, W.F.; Zhang, F.S. Establishing a Regional Nitrogen Management Approach to Mitigate Greenhouse Gas Emission Intensity from Intensive Smallholder Maize Production. PLoS ONE 2014, 9, 98481. [CrossRef] [PubMed]

23. IPCC. 2006 IPCC Guidelines for National Greenhouse Gas Inventories; Eggleston, H.S., Buendia, L., Miwa, K., Ngara, T., Tanabe, K., Eds.; National Greenhouse Gas Inventories Programme IGES: Tokyo, Japan, 2006; p. 664.

24. Zhang, W.F.; Dou, Z.X.; He, P.; Ju, X.T.; Powlson, D.; Chadwick, D.; Norse, D.; Lu, Y.L.; Zhang, Y.; Wu, L.; et al. New technologies reduce greenhouse gas emissions from nitrogenous fertilizer in China. Proc. Natl. Acad. Sci. USA 2013, 110, 8375-8380. [CrossRef] [PubMed]

25. Yuan, B.R.; Nie, Z.R.; Di, X.H.; Zuo, T.Y. Life cycle inventories of fossil 538 fuels in China (II): Final life cycle inventories. Mod. Chem. Ind. 2006, 26, 59-61.

26. Brentrup, F.; Pallière, C. GHG Emission and Energy Efficiency in European Nitrogen Fertilizer Production and Use; IFA Proceedings No. 639; International Fertiliser Society: Colchester, UK, 2008.

27. Williams, A.G.; Audsley, E.; Sandars, D.L. Determining the Environmental Burdens and Resource Use in the Production of Agricultural and Horticultural Commodities; Department for Environment, Food and Rural Affairs: London, UK, 2006.

28. Ierna, A.; Pandino, G.; Lombardo, S.; Mauromicale, G. Tuber yield, water and fertilizer productivity in early potato as affected by a combination of irrigation and fertilization. Agric. Water Manag. 2011, 101, 35-41. [CrossRef]

29. Zhang, F.S.; Chen, X.P.; Chen, Q. Guidelines for Major Crop Fertilization in China; China Agriculture Press: Beijing, China, 2009; pp. 88-91.

30. Vinyes, E.; Gasol, M.C.; Asin, L.; Alegre, S.; Muñoz, P. Life Cycle Assessment of multiyear peach production. J. Clean. Prod. 2015, 104, 68-79. [CrossRef]

31. Yang, Z.L.; Fu, J.L.; Gao, T.Y.; Chai, D.D.; Wu, Y.J.; Li, Z.X.; Wang, L.F. Research on carbon footprint for management activity of urban modern agriculture in Beijing: A case study of Pyrus ussuriensis Maxin. cv. Jingbaili orchards in Mentougou District. Chin. Agric. Sci. Bull. 2016, 32, 128-134.

32. Yang, Z.F.; Cong, P.H.; Nie, J.Y.; Wang, X.D.; Li, H.F. Current situation, future development direction and suggestions of fruit industry in China. In Proceedings of the Seventh Youth Symposium of the Chinese Horticultural Society, Chengdu, China, 26-28 September 2006; pp. 701-704.

33. Cheng, K.; Pan, G.X.; Smith, P.; Luo, T.; Li, L.Q.; Zhang, J.W.; Zhang, X.H.; Han, X.J.; Yan, M. Carbon footprint of China's crop production-an estimation using agro statistics data over 1993-2007. Agric. Ecosyst. Environ. 2011, 142, 231-237. [CrossRef]

34. Yuan, Y.B. Research of Nutrient Management in Peach Orchard in Pinggu Country Beijing City. Master's Thesis, Huazhong Agricultural University, Wuhan, China, 2007.

35. Kou, C.L.; Ju, X.T.; Zhang, F.S. Nitrogen balance and its effects on nitrate-N concentration of groundwater in three intensive cropping systems of North China. Chin. J. Appl. Ecol. 2005, 16, 660-667.

36. Yan, Z.J.; Duan, Z.Q.; Lu, S.C.; Chen, Q. Construction and application of regional fertilization decision-making system based on Google Map and Web GIS for peach orchard. Trans. Chin. Soc. Agric. Eng. 2010, 26, 207-212. 
37. Li, F.G.; Meng, Y.H.; Jia, X.H.; Chen, Q.; Xu, X.F.; Han, Z.H. Effects of nitrogen applied rate on fruit yield, quality and leaf nutrient content of 'Bayuecui' peach. Plant Nutr. Fertil. Sci. 2006, 12, 918-921.

38. Vinyes, E.; Asin, L.; Alegre, S.; Muñoz, P.; Boschmonart, J.; Gasol, C.M. Life Cycle Assessment of apple and peach production, distribution and consumption in Mediterranean fruit sector. J. Clean. Prod. 2017, 149, 313-320. [CrossRef]

39. Zhang, S.S.; Peng, F.T.; Jiang, Y.M.; Li, D.D.; Zhu, C.F.; Peng, J. Effects of bag controlled-release fertilizer on nitrogen utilization rate, growth and fruiting of peach. Plant Nutr. Fertil. Sci. 2008, 14, 379-386.

40. Xie, X.; Cai, W.J.; Jiang, Y.K.; Zeng, W.H. Carbon footprints and embodied carbon flows analysis for China's eight regions: A new perspective for mitigation solutions. Sustainability 2015, 7, 10098-10114. [CrossRef]

(C) 2018 by the authors. Licensee MDPI, Basel, Switzerland. This article is an open access article distributed under the terms and conditions of the Creative Commons Attribution (CC BY) license (http://creativecommons.org/licenses/by/4.0/). 